\title{
KONSENTRASI ASAM ASETAT MEMENGARUHI KARAKTERISTIK FISIKOKIMIA PATI SAGU IHUR TERASETILASI
}

\author{
[Acetid Acid Concentration Treatment Affects the Physicochemical Characteristics of \\ Acetylated Ihur Sago Starch]
}

\author{
Febby J. Polnaya ${ }^{1,2) \star}$, Hilda ${ }^{1)}$, dan Cynthia G.C. Lopulalan ${ }^{1)}$ \\ 1) Jurusan Teknologi Hasil Pertanian, Fakultas Pertanian, Universitas Pattimura, Ambon \\ ${ }^{2)}$ Pusat Studi Ilmu Pangan, Universitas Pattimura, Ambon
}

Diterima 19 Maret 2019 / Disetujui 2 November 2020

\begin{abstract}
Native ihur sago starch is a starch from Maluku and to date there is no report on its physicochemical properties. The objective of this work was to evaluate the effect of acetic acid concentration on the physicochemical properties of the native ihur sago starch. The starch was acetylated at different acetic acid concentrations, i.e., $0,0.5,1.5$, and $2.5 \%$. The acetylation was carried out by reacting ihur sago starch solution (100 g in $225 \mathrm{~mL}$ water) with acetic acid under alkaline condition. The acetyl group, degree of substitution (DS), water solubility, swelling power, paste clarity, and water, ash and amylose contents of the acetylated starch were measured. The study was conducted in three replications of non-factorial experiments using a completely randomized design. Starch modification through acetic acid addition produced ihur sago starch with different physicochemical characteristics than that of its native form. The acetylation caused the hydroxyl group in the starch to be substituted by acetyl group at concentration of $1.336-1.850 \%$ and DS range of 0.026-0.046, whilst no acetyl group was detected in its native starch. Acetylation increased the starch ash content from $0.46 \%$ to $0.50-0.57 \%$, amylose content from $28.86 \%$ to 29.73-31.46\%, solubility from $12.83 \%$ to $14.20-25.20 \%$, swelling power from $18.51 \mathrm{~g} / \mathrm{g}$ to $16.74-28.24 \mathrm{~g} / \mathrm{g}$ and paste clarity from $93.07 \% T_{650}$ to $93.50-94.13 \% T_{650}$. In addition, acetylation at $0.5 \%$ increased the water content of the starch while higher concentration of acetylation could decrease its water content.
\end{abstract}

Keywords: acetylation, acetic acid concentration, ihur sago starch

\begin{abstract}
ABSTRAK
Pati sagu ihur alami (PSIA) merupakan pati dari daerah Maluku yang belum banyak diteliti sifat-sifat fisikokimianya. Penelitian ini bertujuan mengkarakterisasi PSIA yang diasetilasi dengan konsentrasi asam asetat yang berbeda yaitu $0,0,5,1,5$ dan $2,5 \%$. Proses asetilasi dilakukan dengan cara mereaksikan PSIA sebanyak $100 \mathrm{~g}$ di dalam $225 \mathrm{~mL}$ air, dengan menambahkan asam asetat dalam kondisi alkali. Analisis PSIA dan pati sagu ihur asetat (PSIAs) meliputi gugus asetil dan derajat subsitusi (DS), daya larut dan daya gelembung pati, kejernihan pasta pati, kadar air, kadar abu, dan kadar amilosa. Rancangan acak lengkap non-faktorial digunakan dalam penelitian ini dan setiap perlakuan diulang tiga kali. Modifikasi pati menggunakan asam asetat menghasilkan PSIAs dengan karakteristik fisikokimia yang berbeda dibandingkan PSIA. Asetilasi pati menyebabkan gugus hidroksil pati tersubstitusi oleh gugus asetil dengan konsentrasi $1,336-1,850 \%$, sedangkan pada PSIA tidak terdeteksi gugus asetil, dengan DS-nya adalah 0,026-0,046. Asetilasi meningkatkan kadar abu pati dari 0,46\% menjadi $0,50-0,57 \%$, kadar amilosa dari $28,86 \%$ menjadi $29,73-31,46 \%$, daya larut dari $12,83 \%$ menjadi $14,20-25,20 \%$, daya gelembung dari 18,51 $\mathrm{g} / \mathrm{g}$ menjadi $16,74-28,24 \mathrm{~g} / \mathrm{g}$ dan kejernihan pasta dari $93,07 \% T_{650}$ menjadi $93,50-94,13 \% T_{650}$. Disisi lain, asetilasi pati dengan $0,5 \%$ asam asetat dapat meningkatkan kadar air tetapi penambahan asam asetat pada konsentrasi yang lebih tinggi akan mengakibatkan penurunan kadar air
\end{abstract}

Kata kunci: asetilasi, konsentrasi asam asetat, pati sagu ihur

\footnotetext{
*Penulis Korespondensi:

E-mail: febby.polnaya@faperta.unpatti.ac.id
} 


\section{PENDAHULUAN}

Sagu merupakan salah satu komoditas potensial di Indonesia, khususnya Indonesia bagian timur, tetapi potensinya belum dimanfaatkan secara maksimal sebagai sumber karbohidrat. Substitusi bahan pangan dan bahan baku industri merupakan salah satu pemanfaatannya. Optimalisasi pemanfaatan pati sagu akan meningkatkan keterkaitan antara industri, mengurangi ketergantungan impor terhadap tepung lainnya dan menumbuhkan industri rumah tangga berbahan dasar pati sagu. Pati alami mempunyai keterbatasan dalam penggunannya, seperti gel yang tidak stabil, kehilangan viskositas dan ketidaklarutan dalam air dingin, telah membatasi penggunaan pati dalam aplikasi industri (Abiddin et al., 2018). Pati sagu ihur alami (PSIA) juga memiliki keterbatasan yang relatif sama, sehingga untuk meningkatkan pemanfaatannya, diperlukan teknik modifikasi tertentu untuk menghasilkan fungsionalitas tertentu pula. PSIA merupakan salah satu jenis pati sagu yang banyak dimanfaatkan oleh masyarakat di provinsi Maluku sebagai bahan pangan lokal. Pemanfaatan PSIA untuk industri masih sangat terbatas.

Modifikasi pati dapat dilakukan dengan beberapa cara, seperti modifikasi fisik dan kimiawi. Modifikasi kimiawi meliputi ikatan silang (crosslink), hidrolisis asam, oksidasi, dekstrinasi, dan konversi asam (Din et al., 2017). Modifikasi kimia menghasilkan pati dengan sifat tahan terhadap panas, asam serta mengurangi sifat sineresis pada pati. Modifikasi pati secara kimiawi telah banyak digunakan untuk menghasilkan sifat-sifat pati yang baru dan dapat digunakan untuk aplikasi yang berbeda. Metode kimiawi yang paling umum digunakan untuk memodifikasi pati adalah modifikasi secara asetilasi, hidroksipropil, dan ikat silang (Hong et al., 2016).

Asetilasi merupakan salah satu modifikasi kimiawi yang banyak digunakan, karena dapat meningkatkan sifat fisikokimia dan fungsional pati, seperti meningkatkan daya gelembung (Amalia dan Kumoro, 2016; Saputro et al., 2012; Singh et al., 2012; Teja et al., 2008; Zięba et al., 2013), kemampuan menahan air (Mbougueng et al., 2012), dan meningkatkan kejernihan pasta pati (Polnaya et al., 2008; Singh et al., 2012; Singh et al., 2004; Teja et al., 2008). Prinsip dari metode ini yaitu mengganti gugus hidroksil $(-\mathrm{OH})$ dengan gugus asetil. Pati asetat merupakan produk asetilasi pati, ditunjukkan oleh esterifikasi gugus asetat pada granula pati, yang mensubstitusi gugus - $\mathrm{OH}$ pati (Hong et al., 2016; Singh et al., 2014).

Penelitian sebelumnya tentang pati sagu asetat telah dilakukan, tetapi asetilasinya menggunakan reagen asetat anhidrida (Polnaya et al., 2010). Hasil penelitian tersebut menunjukkan bahwa karakteristik dari pati sagu seperti daya gelembung, daya larut, stabilitas beku cair dan kejernihan pasta, yang cenderung lebih tinggi dibandingkan pati sagu alaminya. Asetilasi pati-pati lainnya juga dilakukan, tetapi lebih umum menggunakan reagen asetat anhidrida. Asetilasi pati kentang dan singkong menggunakan asetat anhidrida meningkatkan kapasitas menahan air dan daya larut, tetapi menurunkan $\mathrm{pH}$, suhu gelatinisasi dan entalpi gelatinisasi (Mbougueng et al., 2012). Asetilasi pati sorgum menggunakan asetat anhidrida menghasilkan pati dengan sifat-sifat gelatinisasi lebih rendah dibandingkan pati alaminya, meliputi suhu gelatinisasi, entalpi, viskositas pasta, kekuatan pasta, dan retrogradasi (Singh et al., 2012).

Asetilasi PSIA, sejauh ini belum dilakukan dengan reagen asam asetat, untuk itu diperlukan penelitian untuk mempelajari karakteristiknya. Penelitian ini bertujuan untuk mengkarakteristik sifat fisikokimia PSIA yang diasetilasi menggunakan beberapa konsentrasi asam asetat, meliputi konsentrasi gugus asetil dan derajat substitusi (DS), daya larut, daya gelembung, kejernihan pasta pati, kadar air, kadar abu dan kadar amilosanya.

\section{BAHAN DAN METODE}

\section{Bahan}

Bahan utama yang digunakan dalam penelitian ini adalah PSIA yang didapatkan pada Oktober, 2016. Pati tersebut merupakan hasil ekstraksi petani lokal di Desa Tulehu, Kabupaten Maluku Tengah.

\section{Metode penelitian}

Pati sagu ihur asetat (PSIAs) dihasilkan dengan memodifikasi pati menggunakan tiga konsentrasi asam asetat ( $\mathrm{v} / \mathrm{b})$ (Merck, Jerman) yaitu 0,5\% $\left(P S I A s_{0,5}\right), 1,5 \%\left(P S I A s_{1,5}\right)$, dan 2,5\% $\left(\mathrm{PSIAs}_{2,5}\right)$. PSIA digunakan sebagai pembanding. Analisis PSIA dan PSIAs meliputi konsentrasi gugus asetil dan DS, daya larut, daya gelembung, kejernihan pasta pati, kadar air, kadar abu dan kadar amilosanya.

\section{Asetilasi pati sagu}

Pati sagu hasil ekstraksi petani dibersihkan di laboratorium, selanjutnya disimpan dalam wadah plastik polietilen densitas tinggi (high-density polyethylene, HDPE) sampai dengan saat digunakan.

Asetilasi PSIA dengan asam asetat mengikuti metode Polnaya et al. (2008) yaitu, pati sagu sebanyak $100 \mathrm{~g}$ didispersikan dalam $225 \mathrm{~mL}$ akuades, dihomogenkan menggunakan magnetik stirer selama 60 menit, pada suhu $25^{\circ} \mathrm{C}$. pH suspensi pati diatur menjadi 8,0 dengan penambahan $\mathrm{NaOH} 3 \%$ (Merck). Asam asetat dengan konsentrasi 0,5\% $\left(\mathrm{PSIAs}_{0,5}\right) ; 1,5 \%\left(\mathrm{PSIAs}_{1,5}\right)$ dan 2,5\% $\left(\mathrm{PSIAs}_{2,5}\right)(\mathrm{v} / \mathrm{v})$ ditambahkan pada suspensi pati. pH diatur menjadi 8,0-8,4, dengan penambahan asam asetat secara bergantian dengan larutan $\mathrm{NaOH} 3 \%$ hingga pe- 
nambahan asam asetat selesai. Reaksi dibiarkan selama 10 menit setelah penambahan asam asetat, setelah itu $\mathrm{pH}$ suspensi pati diatur menjadi 4,5 dengan penambahan $\mathrm{HCl} 0,5 \mathrm{~N}$ (Merck) untuk menghentikan reaksi. Pati yang dihasilkan kemudian disaring dan endapannya dicuci dengan akuades sebanyak enam kali dan dikeringkan menggunakan pengering kabinet pada suhu $50^{\circ} \mathrm{C}$ selama 9 jam. PSIAs dihaluskan dan diayak untuk memperoleh pati yang lolos ayakan 80 mesh. Pati selanjutnya disimpan dalam wadah plastik HDPE.

\section{Analisis gugus asetilasi dan derajat substitusi (DS)}

Pengujian gugus asetil (\%) dan DS digunakan untuk mengetahui banyaknya gugus asetil yang tersubsitusi ke dalam PSIAs. Analisisnya menggunakan metode yang dikemukakan oleh Shah et al. (2017) yaitu sebanyak $1 \mathrm{~g}$ pati dicampur dengan 50 $\mathrm{mL}$ etanol $75 \%$, dimasukkan ke dalam labu takar $250 \mathrm{~mL}$. Labu takar ditutup dengan alumunium foil dan dimasukkan ke dalam penangas air (Memmert, Jerman) pada suhu $50^{\circ} \mathrm{C}$, selama 30 menit. Sampel kemudian didinginkan dan ditambahkan $40 \mathrm{~mL}$ 0,5 N $\mathrm{KOH}$. Sampel disimpan dengan pengadukan konstan pada $200 \mathrm{rpm}$ selama 72 jam. Kelebihan alkali kemudian dititrasi dengan $0,05 \mathrm{~N} \mathrm{HCl}$ dengan menggunakan indikator fenolftalein. Persentase asetil dihitung menggunakan persamaan berikut (Shah et al., 2017):

$\%$ Asetil $=\frac{(\text { blanko-sampel }) \times \mathrm{N}_{\mathrm{HCl}}+0,043 \times 100}{\text { berat sampel }} \ldots \ldots$.

Blanko adalah volume $\mathrm{HCl}$ untuk titrasi pati sagu alami. Sampel adalah volume $\mathrm{HCl}$ untuk titrasi sampel. $\mathrm{N}_{\mathrm{HCl}}$ adalah normalitas $\mathrm{HCl}$ yang digunakan untuk titrasi. 0,043 adalah miliekuivalen gugus asetil.

Derajat subtitusi dihitung menggunakan persamaan berikut (Shah et al., 2017):

$\mathrm{DS}=\frac{162 \times \% \text { asetil }}{(43 \times 100)-(42 \times \% \text { asetil })}$

DS $=$ derajat substitusi; $162=$ berat molekul gu gus satuan anhidroglukosa; $43=$ berat molekul gugus asetil; $42=$ berat molekul gugus asetil -1 .

\section{Analisis daya larut dan daya gelembung pati}

Analisis daya gelembung dan daya larut pati megikuti metode yang dikemukakan oleh Picauly et al. (2017). Pati didispersikan dalam akuades (1\%, $\mathrm{b} / \mathrm{v}$ ) pada tabung reaksi yang telah diketahui beratnya $\left(\mathrm{W}_{1}\right)$. Dispersi pati dipanaskan menggunakan penangas air (Memmert) pada suhu $95^{\circ} \mathrm{C}$, selama 30 menit, lalu didinginkan hingga suhu kamar $\left(27^{\circ} \mathrm{C}\right)$. Suspensi pati dipisahkan dengan sentrifu- gasi (Hermle, Jerman) pada $5000 \mathrm{rpm}$ selama 15 menit, sehingga terpisah residu dan supernatan. Residu hasil sentrifugasi kemudian ditimbang $\left(\mathrm{W}_{2}\right)$. Daya gelembung pati (berdasarkan berat kering) ditentukan sebagai berikut:

Daya Gelembung $(\mathrm{g} / \mathrm{g})=\frac{\left(\mathrm{W}_{2}-\mathrm{W}_{1}\right)}{\text { berat pati }}$

Alikuot $(10 \mathrm{~mL})$ dari supernatan dikeringkan hingga berat konstan pada suhu $110^{\circ} \mathrm{C}$. Residu yang terdapat setelah dikeringkannya supernatan, menunjukkan jumlah pati terlarut (\%).

\section{Analisis kejernihan pasta}

Analisis kejernihan pasta pati mengacu pada metode yang dikemukakan oleh Picauly et al. (2017). Suspensi pati $(2 \%, w / v)$ dipanaskan pada penangas air dengan suhu $90^{\circ} \mathrm{C}$, selama 30 menit sambil dikocok. Suspensi didinginkan hingga suhu $\pm 30^{\circ} \mathrm{C}$, kemudian disimpan pada suhu $4^{\circ} \mathrm{C}$ selama 24 jam dan dilakukan pengukuran kejernihan pasta didasarkan nilai transmitansi $(\% T)$. Transmitansi diukur dengan spektrofotometer UV-Vis spektrofotometer (Genesys $10 \mathrm{~S}$, Tiongkok) pada $\lambda 650 \mathrm{~nm}$ $\left(\% T_{650}\right)$. Akuades digunakan sebagai blanko.

\section{Analisis kadar air}

Metode gravimetri AOAC 925.10 (AOAC, 2012) digunakan untuk menganalisis kadar air pati sagu alami dan derifatnya. Sebanyak $1 \mathrm{~g}$ sampel pati dimasukkan dalam botol timbang yang telah diketahui berat konstannya. Sampel dikeringkan menggunakan oven (Memmert) pada suhu $105^{\circ} \mathrm{C}$, didinginkan dalam desikator dan ditimbang sampai berat konstan. Perhitungan kadar air sampel didasarkan pada perbedaan berat sebelum dan sesudah sampel dikeringkan.

\section{Analisis kadar abu}

Metode AOAC 923.03 (AOAC, 2012) digunakan untuk analisis kadar abu sampel pati sagu alami dan derifatnya. Sebanyak $5 \mathrm{~g}$ sampel pati dimasukkan dalam cawan porselin bersih dan diketahui berat konstannya. Sampel diarangkan menggunakan pemanas listrik sampai tidak berasap dan selanjutnya diabukan dalam tanur pengabuan (Vulcan A-550 Ney, Amerika Serikat) pada suhu $650^{\circ} \mathrm{C}$ sampai dihasikan abu yang berwarna putih keabu-abuan. Kadar abu sampel ditentukan dengan menimbang berat konstan sisa mineral hasil pembakaran bahan organik.

\section{Analisis kadar amilosa}

Kadar amilosa pati dianalisa megikuti metode yang dikemukakan oleh Wulandari et al. (2019). Pati sebanyak $100 \mathrm{mg}$ ditimbang dalam tabung reaksi 50 $\mathrm{mL}$. Etanol 95\% (Sigma-Aldrich, Jerman) sebanyak 
$1 \mathrm{~mL}$ dan $9 \mathrm{~mL} \mathrm{NaOH} 1 \mathrm{M}$ (Merck) ditambahkan, lalu dihomogenkan dengan divorteks. Didihkan selama 10 menit dan diencerkan hingga $100 \mathrm{~mL}$. Larutan sampel sebanyak $5 \mathrm{~mL}$ dimasukkan ke dalam labu takar $100 \mathrm{~mL}$ dan ditambahkan dengan $1 \mathrm{~mL}$ larutan asam asetat $1 \mathrm{~N}$ (Merck) dan $2 \mathrm{~mL}$ larutan iodium 0,01 N (Merck), dan akuades sampai batas tera. Larutan dipanaskan pada suhu $30^{\circ} \mathrm{C}$ selama 20 menit. Intensitas warna biru diukur absorbansinya menggunakan UV-Vis spektrofotometer pada $\lambda 620 \mathrm{~nm}$. Absorbansi yang diperoleh diplotkan pada kurva standar dan kadar amilosa dihitung berdasarkan hubungan absorbansi sampel dengan kadar amilosa pada pada kurva standar.

\section{Analisis statistik}

Penelitian menggunakan rancangan acak lengkap dengan tiga ulangan. Uji Tukey pada taraf $95 \%$ $(\alpha=0,05)$ digunakan untuk mengetahui perbedaan di antara rataan perlakuan tersebut. Data dianalisis menggunakan analisis keragaman dengan bantuan program Minitab 18.

\section{HASIL DAN PEMBAHASAN}

\section{Gugus asetil dan derajat substitusi (DS)}

Perlakuan konsentrasi asam asetat berpengaruh sangat nyata $(P<0,01)$ terhadap peubah gugus asetil dan DS PSIAs. Hal ini menunjukkan bahwa gugus asetil dan DS PSIAs dipengaruhi oleh perlakuan asetilasi dan meningkatkan nilainya. Asetilasi pati menyebabkan gugus hidroksil PSIAs tersubstitusi oleh gugus asetil dengan nilai 1,338-1,850\%. Gugus asetil tidak terdeteksi pada PSIA. Berdasarkan persentase gugus asetil, maka dihitung nilai DS dan diperoleh kisarannya adalah 0,026-0,046. Dapat dilihat bahwa taraf perlakuan PSIAs 2,5 berbeda nyata dengan semua perlakuan lainnya (Tabel 1 ) berdasarkan uji Tukey $(\alpha=0,05)$. Perbedaan ini menunjukkan bahwa gugus asetil terikat pada granula pati sagu melalui proses modifikasi yang dilakukan. Meningkatnya konsentrasi asam asetat yang digunakan menyebabkan semakin meningkatkan konsentrasi gugus asetil dan juga derajat substitusi. Peningkatan ini disebabkan karena pada kondisi modifikasi yang sama tetapi konsentrasi reagen modifikasi yang meningkat, menyebabkan kemungkinan interaksi antara reagen dengan pati dan menyebabkan tersubstitusinya gugus hidroksil pati sagu oleh gugus asetil semakin besar. Hal ini menyebakan pati sagu yang diasetilasi dengan asam asetat konsentrasi tinggi $\left(\mathrm{PSIAs}_{2,5}\right.$ ) mempunyai konsentrasi gugus asetil dan nilai DS lebih tinggi.

Melalui proses modifikasi maka terjadi peningkatan nilai gugus asetil dan DS PSIAs. Nilai gugus asetil dan DS meningkat seiring dengan meningkatnya konsentrasi asam asetat. Meningkatnya gugus asetil disebabkan karena pada kondisi alkali akan memudahkan gugus $-\mathrm{OH}$ tersubstitusi oleh gugus asetil, sehingga ikatan hidrogen pati menjadi lemah (Teja et al., 2008). Meningkatnya gugus asetil secara langsung berpengaruh juga pada meningkatnya nilai DS. Beberapa hasil penelitian sebelumnya tentang pati asetat menunjukkan nilai DS yang relatif sama dengan penelitian ini, yaitu pada pati sagu asetil 0,056, 0,061, dan 0,088 (Polnaya et al., 2010; Polnaya et al., 2008; Teja et al., 2008), pati talas asetil 0,13 (Saputro et al., 2012), pati oat asetil 0,05 (Shah et al., 2017), tepung gadung asetil 0,18 (Kumoro et al., 2014), dan tepung jagung asetil 0,21 (Ayucitra, 2012). Menurut Colussi et al. (2015), pati asetat dengan DS rendah $(0,01-0,2)$ dapat diaplikasikan pada berbagai macam produk pangan sesuai dengan sifat-sifat yang dibutuhkan bahan pangan tersebut, seperti misalnya produk pangan beku dan produk lainnya, tetapi berdasarkan hasil penelitian sebelumnya menunjukkan bahwa terdapat juga asetilasi pati yang menghasilkan pati asetat dengan DS yang relatif tinggi dibandingkan hasil penelitian ini. Penelitian Harianingsih dan Wibowo (2016), menunjukkan nilai DS pati sorgum asetat sebesar $0,45-2,79$. Perbedaan ini mungkin dapat disebabkan karena perbedaan kondisi modifikasi yang digunakan. Menurut Colussi et al. (2015), asetilasi pati yang dilakukan pada kondisi media berair dan alkali, menghasilkan pati dengan DS yang rendah, seperti yang dihasilkan pada penelitian ini.

Tabel 1. Pengaruh asetilasi menggunakan asam asetat terhadap karakteristik pati sagu asetat

\begin{tabular}{|c|c|c|c|c|}
\hline \multirow{2}{*}{ Pengamatan } & \multicolumn{4}{|c|}{ Konsentrasi Asam Asetat (\%) } \\
\hline & PSIA & $\mathrm{PSIAS}_{0,5}$ & $\mathrm{PSIAs}_{1,5}$ & $\mathrm{PSIAS}_{2,5}$ \\
\hline Gugus asetil (\%) & $\mathrm{td}$ & $1,336 \pm 0,003^{\mathrm{C}}$ & $1,568 \pm 0,002^{b}$ & $1,850 \pm 0,009^{a}$ \\
\hline Derajat substitusi & td & $0,026 \pm 0,003^{\mathrm{C}}$ & $0,035 \pm 0,002^{b}$ & $0,046 \pm 0,009^{a}$ \\
\hline Daya larut (\%) & $12,83 \pm 1,65^{\mathrm{c}}$ & $14,20 \pm 2,55 b^{c}$ & $18,60 \pm 1,67^{\mathrm{b}}$ & $25,20 \pm 1,82^{\mathrm{a}}$ \\
\hline Daya gelembung $(\mathrm{g} / \mathrm{g})$ & $18,51 \pm 0,97^{\mathrm{C}}$ & $22,65 \pm 1,09^{b}$ & $28,24 \pm 0,52^{a}$ & $16,74 \pm 1,51^{\mathrm{c}}$ \\
\hline Kejernihan $\left(\% T_{650}\right)$ & $93,07 \pm 0,15^{\mathrm{b}}$ & $93,50 \pm 0,26^{\mathrm{ab}}$ & $93,77 \pm 0,38^{a b}$ & $94,13 \pm 0,40^{a}$ \\
\hline Kadar air (\%) & $9,67 \pm 0,02^{b}$ & $10,02 \pm 0,15^{\mathrm{a}}$ & $9,54 \pm 0,06^{\mathrm{b}}$ & $9,24 \pm 0,10^{c}$ \\
\hline Kadar abu (\%) & $0,46 \pm 0,02^{\mathrm{b}}$ & $0,50 \pm 0,05^{\mathrm{ab}}$ & $0,52 \pm 0,03^{a b}$ & $0,57 \pm 0,02^{\mathrm{a}}$ \\
\hline Kadar amilosa (\%) & $28,86 \pm 0,51^{\mathrm{b}}$ & $29,73 \pm 0,82^{\mathrm{ab}}$ & $30.35 \pm 1,01^{\mathrm{ab}}$ & $31,46 \pm 1,16^{\mathrm{a}}$ \\
\hline
\end{tabular}

Keterangan: PSIA = pati sagu ihur alami. PSIAs $=$ pati sagu ihur asetat. $t d=$ tidak terdeteksi. Data disajikan dalam bentuk nilai rata-rata \pm SD dari tiga ulangan. Angka yang diikuti huruf yang sama pada baris yang sama menunjukkan tidak berbeda nyata berdasarkan uji Tukey $(\alpha=0,05)$ 


\section{Daya larut}

Perlakuan konsentrasi asam asetat berpengaruh sangat nyata $(P<0,01)$ terhadap peubah daya larut PSIAs. Hal ini menunjukkan bahwa daya larut pati dipengaruhi oleh perlakuan asetilasi. Modifikasi pati asetat meningkatkan daya larut pasta menjadi $14,20-25,20 \%$ dari PSIA yaitu $12,83 \%$. Dapat dilihat bahwa pengaruh konsentrasi asam asetat tertinggi $2,5 \%$ berbeda nyata dengan semua perlakuan konsentrasi asam asetat lainnya (Tabel 1) berdasarkan uji Tukey $(\alpha=0,05)$. Perlakuan PSIA menunjukkan tidak berbeda nyata dengan rataan perlakuan $\mathrm{PSIAs}_{0,5}$, demikian juga perlakuan $\mathrm{PSIAs}_{0,5}$ dan PSIAs ${ }_{1,5}$. Perbedaan sifat daya larut pati sagu asetat menunjukkan bahwa gugus modifikasi memengaruhi sifat tersebut, dan semakin tinggi konsentrasi gugus asetil atau DS, maka daya larutnya semakin tinggi. Penelitian Amalia dan Kumoro (2016) juga menunjukkan bahwa semakin banyak asam asetat glasial yang ditambahkan, maka daya larut tepung gadung asetat meningkat.

Meningkatnya daya larut PSIAs disebabkan karena terjadi perubahan pada struktur granula pati. Gugus -OH pada PSIA yang tersubsitusi oleh gugus asetil, menyebabkan melemahnya ikatan hidrogen granula pati. Melemahnya ikatan tersebut, memudahkan air masuk ke dalam granula pati sehingga meningkatkan kelarutannya (Mbougueng et al., 2012; Singh et al., 2004).

Pada proses modifikasi, meningkatnya konsentrasi asam asetat menyebabkan semakin tinggi reduksi amilopektin, sehingga patinya semakin mudah larut dalam air. Kemudahan ini meningkatkan persentase daya larut. Beberapa hasil penelitian menunjukkan hasil yang sama untuk pati sagu asetat $19,85 \%$ (Polnaya et al., 2008) dan pati jagung asetat 9,50-17,38 (Ayucitra, 2012).

\section{Daya gelembung}

Perlakuan konsentrasi asam asetat berpengaruh sangat nyata $(P<0,01)$ terhadap peubah daya gelembung pasta. Hal ini menunjukkan bahwa daya gelembung pati sagu dipengaruhi oleh perlakuan asetilasi. Modifikasi pati asetat meningkatkan daya gelembung PSIAs menjadi $28,24 \mathrm{~g} / \mathrm{g}$ dibandingkan PSIA yaitu $18,51 \mathrm{~g} / \mathrm{g}$. Perlakuan PSIAs ${ }_{1,5}$ menghasilkan daya gelembung tertinggi. Perlakuan tersebut berbeda nyata dengan perlakuan konsentrasi asam asetat lainnya (Tabel 1 ) berdasarkan uji Tukey $(\alpha=$ $0,05)$.

Daya gelembung PSIAs ini juga sejalan dengan penelitian Amalia dan Kumoro (2016) yang mengemukakan bahwa, meningkatnya penambahan konsentrasi asam asetat glasial, menyebabkan daya gelembung tepung gadung asetat meningkat. Meningkatnya daya gelembung ini juga ditunjukkan oleh Saputro et al. (2012) untuk pati talas asetat, Polnaya et al. (2008) untuk pati sagu hidroksipropil-asetat, dan Zięba et al. (2013) pati kentang asetat. Meningkatnya konsentrasi asam asetat sampai dengan $1,5 \%$ menyebabkan daya gelembung PSIAs juga meningkat. Meningkatnya daya gelembung pati disebabkan karena ikatan hidrogen antara molekul pati melemah, karena tersubsitusinya gugus asetil, yang akhirnya menyebabkan reorganisasi struktur granula pati, sebagai akibat halangan sterik (Hu et al., 2016) sehingga struktur granula pati menjadi kurang rapat (Saputro et al., 2012; Polnaya et al., 2008). Kurang rapatnya struktur granula pati, meningkatkan kesempatan air masuk ke bagian amorf pati, sehingga meningkatkan hidrasi dan menggelembungnya granula pati (Amalia dan Kumoro, 2016).

Hasil yang sama juga teramati pada pati jagung asetat yaitu sebesar $27,85 \mathrm{~g} / \mathrm{g}$ dari pati alaminya $15,15 \mathrm{~g} / \mathrm{g}$ (Ayucitra, 2012). Menurut Mbougueng et al. (2012), asetilasi menyebabkan peningkatan kemampuan menahan air pati kentang dan singkong asetat. Meningkatnya kemampuan menahan air pati merupakan indikator kemudahan granula pati lebih untuk mengembang. Teja et al. (2008) menyatakan bahwa sebagai akibat dari subtitusi gugus asetil, maka dapat melemahkan ikatan hidrogen pada pati sagu. Air menjadi lebih mudah terpenetrasi ke dalam granula pati yang menyebabkan granula pati menjadi lebih mudah menggelembung.

Perlakuan konsentrasi PSIAs ${ }_{2,5}$ menunjukkan bahwa terjadi penurunan daya gelembung pati asetat dan lebih rendah dibandingkan PSIA. Hal ini mungkin disebabkan karena pada DS yang tinggi meningkatkan penetrasi air yang dapat merusak struktur granula lebh lanjut pada saat pemanasan, sehingga granula tidak lagi menggelembung secara sempurna dan menurunkan daya gelembung $\mathrm{PSIAs}_{2,5}$.

\section{Kejernihan pasta pati}

Perlakuan konsentrasi asam asetat berpengaruh sangat nyata $(P<0,05)$ terhadap peubah kejernihan pasta PSIAs. Hal ini menunjukkan bahwa kejernihan pati sagu dipengaruhi oleh perlakuan asetilasi. Modifikasi pati asetat meningkatkan daya gelembung menjadi $94,13 \%$ dari pati alaminya yaitu 93,07\%. Dapat dilihat bahwa pengaruh konsentrasi asam asetat tertinggi yaitu perlakuan $\mathrm{PSIAs}_{2,5}$ tidak berbeda nyata dengan konsentrasi asam asetat $\mathrm{PSIAs}_{0,5}$, dan PSIAs ${ }_{1,5}$ namun berbeda nyata dengan perlakuan PSIA (Tabel 1) berdasarkan uji Tukey $(\alpha=0,05)$. Tidak berbedanya rataan perlakuan antara taraf perlakuan $\mathrm{PSIAs}_{0,5}$ dan $\mathrm{PSIAs}_{1,5}$ dapat disebabkan karena perlakuan konsentrasi asam asetat tersebut mungkin belum mampu memengaruhi sifat kejernihan pasta pati.

Perbedaan sifat kejernihan pasta PSIAs dengan PSIA disebabkan karena granula pati asetat lebih mudah merenggang sebagai akibat tersubs- 
titusinya gugus asetil. Terdapat kecenderungan granula pati asetat merenggang antara granula yang berdekatan dan mengurangi asosiasi antar rantai yang memfasilitasi peningkatan $\% T_{650}$ (Polnaya et al., 2008). Meningkatnya kejernihan pasta pati termodifikasi secara asetilasi ditunjukkan oleh beberapa penelitian lainnya untuk pati jagung dan kentang asetat (Singh et al., 2004), pati sagu asetat (Polnaya et al., 2008; Teja et al., 2008), pati sorgum (Singh et al., 2012).

\section{Kadar air}

Perlakuan konsentrasi asam asetat berpengaruh sangat nyata $(P<0,01)$ terhadap peubah kadar air PSIAs. Hal ini menunjukkan bahwa kadar air pati sagu dipengaruhi oleh perlakuan asetilasi. Kadar air pati sagu ihur alami adalah sebesar 9,67\%, jika dibandingkan dengan penelitian Polnaya et al. (2009; 2018) yaitu sebesar 11,6-12,53\%, maka kadarnya lebih rendah. Polnaya et al. (2018) mengemukakan bahwa perbedaan dapat disebabkan karena perbedaan proses pengolahan atau sumber pati sagu ihur.

Asetilasi menyebabkan terjadinya perubahan kadar air PSIAs. Perlakuan PSIAs ${ }_{0,5}$ menyebabkan peningkatan kadar airnya jika dibandingkan dengan PSIA dan keduanya berbeda nyata berdasarkan uji Tukey $(\alpha=0,05)$. Hal ini mungkin disebabkan karena sifat hidrofilitasnya belum terlalu dipengaruhi oleh tersubstitusinya gugus asetil. Modifikasi dengan konsentrasi asam asetat yang lebih tinggi, menyebabkan kadar air $\mathrm{PSIAs}_{1,5}$ dan $\mathrm{PSIAs}_{2,5}$ menurun. Hal ini disebabkan karena sifat hidrofobisitas PSIAs meningkat. Asetilasi menyebabkan tersubstitusinya gugus - $\mathrm{OH}$ yang bersifat hidrofilik dengan gugus asetil. Sehingga semakin tinggi konsentrasi asam asetat maka gugus - $\mathrm{OH}$ yang tersubsitusi oleh gugus asetil semakin meningkat. Peningkatan ini menyebabkan hidrofilisitas semakin menurun dan menyebabkan kadar air pati menurun. Menurunnya kadar air PSIAs dapat juga dipengaruhi oleh kadar amilosa. Singh et al. (2012), mengemukakan bahwa asetilasi menyebabkan perubahan hidrofilisitas pati sorghum fosfat.

\section{Kadar abu}

Perlakuan konsentrasi asam asetat berpengaruh sangat nyata $(P<0,05)$ terhadap peubah kadar abu PSIAs. Hal ini menunjukkan bahwa kadar abu pati sagu dipengaruhi oleh perlakuan asetilasi. Modifikasi pati asetat meningkatkan kadar abu pati menjadi $0,50-0,57 \%$ dari PSIA yaitu 0,46\%. Hasil ini lebih tinggi jika dibandingkan dengan penelitian (Polnaya et al., 2008) sebesar 0,127\%. Kadar abu tertinggi ditunjukkan oleh $\mathrm{PSIAs}_{2,5}$ dan taraf perlakuan tersebut berbeda nyata hanya dengan PSIA (Tabel 1) berdasarkan uji Tukey $(\alpha=0,05)$, sedang- kan taraf perlakuan PSIA, PSIAs ${ }_{0,5}$ dan PSIAs $_{1,5}$ tidak berbeda nyata.

Meningkatnya kadar abu pati asetat dikarenakan adanya kemungkinan ikut terikatnya $\mathrm{Na}$ yang terikat dengan gugus - $\mathrm{OH}$. Esterifikasi berlangsung dalam kondisi alkaline yang memungkinkan terjadinya hal tersebut. Diagram skematik esterifikasi dengan asetat anhidrida yang dikemukakan oleh Hong et al. (2016) menunjukkan bahwa $\mathrm{Na}^{+}$dapat terikat sebagai bagian dari gugus asetil menggantikan gugus -OH pada amilosa. Pada proses pencucian, $\mathrm{Na}^{+}$ yang tidak terikat dengan gugus asetil akan ikut tercuci dengan air, namun masih tertinggal $\mathrm{Na}^{+}$yang sudah terikat dengan gugus asetil sehingga terhitung sebagai abu (mineral).

\section{Kadar amilosa}

Perlakuan konsentrasi asam asetat tidak berpengaruh nyata $(P<0,05)$ terhadap kadar amilosa PSIAs. Hal ini menunjukkan bahwa amilosa pati sagu dipengaruhi oleh perlakuan asetilasi. Modifikasi pati asetat meningkatkan kadar amilosa pati menjadi $31,46 \%$ dari pati alaminya yaitu $28,86 \%$. Dapat dilihat bahwa pengaruh pelakuan $\mathrm{PSIAs}_{2,5}$ tidak berbeda nyata dengan perlakuan PSIAs ${ }_{0,5}$ dan $\mathrm{PSIAs}_{1,5}$, namun berbeda nyata dengan perlakuan $\mathrm{PSIAs}_{0}$ (Tabel 1) berdasarkan uji Tukey $(\alpha=0,05)$. Taraf perlakuan PSIA menunjukkan tidak berbeda nyata dengan PSIAs $s_{0,5}$ dan PSIAs ${ }_{1,5}$. Berat molekul pati sesudah modifikasi adalah lebih besar dibandingkan sebelum modifikasi pada mol yang sama. Perubahan berat molekul tersebut disebabkan tersubstitusinya gugus - $\mathrm{OH}$ pati oleh gugus asetil.

Fraksi amilosa dan amilopektin pati modifikasi mengalami interferensi sebagai akibat tersubstitusinya gugus asetil, sehingga memengaruhi absorbs iodium selama pengujian amilosa (Mbougueng et al., 2012). Saat dianalisis molekul amilopektin hasil degradasi yang berupa molekul linier dan berbentuk heliks ganda tersebut melakukan pengikatan dengan iodium lebih baik dibandingkan sebelum modifikasi sehingga terjadi peningkatan nilai absorbansinya. Singh et al. (2004) menyatakan bahwa kehadiran kelompok-kelompok gugus asetil mengganggu fungsi dari amilosa dan amilopektin pada fraksi pati sehingga memengaruhi penyerapan iodium selama pengujian amilosa.

Meningkanya kadar amilosa sesudah modifikasi juga teramati pada penelitian pati kentang dan singkong asetat (Mbougueng et al., 2012), pati sorgum asetat (Singh et al., 2012), serta pati jagung dan kentang asetat (Singh et al., 2004). Beberapa penelitian lain menunjukkan terjadinya penurunan kadar amilosa untuk pati asetil, seperti yang ditunjukkan oleh Wani et al. (2012) dan Zięba et al. (2013). Sánchez-Rivera et al. (2013) melaporkan bahwa asetilasi pati pisang dan jagung menyebabkan peningkatan fraksi amilopektin rantai pendek jika di- 
bandingkan dengan pati alaminya, sedangkan rantai amilosa sedikit mengalami depolimerisasi. Terjadi peningkatan berat molekul relatif untuk amilosa maupun amilopektin untuk pati kacang hitam asetat ditunjukkan oleh Simsek et al. (2012), dan hal ini memengaruhi analisis kadar amilosa.

\section{KESIMPULAN}

Perlakuan modifikasi asetilasi dengan menggunakan asam asetat menghasilkan PSIAs, dengan karakteristik fisikokimia yang berbeda dibandingkan PSIA. Konsentrasi gugus asetil dan DS PSIAs lebih tinggi dibandingkan dengan PSIA, dan meningkat seiring meningkatkan konsentrasi asam asetat yang digunakan. Tersubstitutinya gugus $-\mathrm{OH}$ oleh gugus asetil menyebabkan peningkatan sifat meliputi daya larut dan daya gelembung pati, kejernihan pasta pati, kadar abu, dan kadar amilosa pati, sedangkan kadar airnya menurun. Sifat daya gelembung pati menurun untuk PSIAs 2,5 . Perlakuan yang direkomendasikan adalah PSIAs ${ }_{2,5}$, karena DS tertinggi menghasilkan sifat-sifat yang dapat menunjang pemanfaatan PSIAs sebagai bahan dasar untuk menghasilkan pangan dengan tingkat kejernihan dan kelarutan yang tinggi.

\section{DAFTAR PUSTAKA}

[AOAC] Association of Official Analytical Chemists. 2012. Official Methods of Analysis of The Association of Official Analytical Chemists. AOAC Inc. Arlington, Virginia.

Abiddin NFZ, Yusoff A, Ahmad N. 2018. Effect of octenylsuccinylation on physicochemical, thermal, morphological and stability of octenyl succinic anhydride (OSA) modified sago starch. Food Hydrocolloid 75: 138-146. DOI: 10.1016/j.food hyd.2017.09.003.

Amalia R, Kumoro AC. 2016. Analisis sifat fisikokimia dan uji korelasi regresi antara nilai derajat substitusi dengan swelling power dan solubility pada tepung gadung (Dioscorea hispida Dennst) terasetilasi. Inovasi Teknik Kimia 1: 17-26.

Ayucitra A. 2012. Preparation and characterisation of acetylated corn starches. Int J Chem Eng Appl 3: 156-159. DOI: 10.7763/IJCEA.2012.V3. 178.

Colussi R, El Halal SLM, Pinto VZ, Bartz J, Gutkoski LC, da Rosa Zavareze E, Dias ARG. 2015. Acetylation of rice starch in an aqueous medium for use in food. LWT-Food Sci Tech 62: 1076-1082. DOI: 10.1016/j.Iwt.2015.01.053.
Din Z-u, Xiong H, Fei P. 2017. Physical and chemical modification of starches - a review. Crit Rev Food Sci Nutr 57: 2691-2705. DOI: 10.1080/ 10408398.2015.1087379.

Harianingsih, Wibowo WA. 2016. Produksi pati sorgum termodifikasi dengan metode asetilasi. Momentum 12: 26-29.

Hong J, Zeng X-A, Brennan CS, Brennan M, Han Z. 2016. Recent advances in techniques for starch esters and the applications - a review. Foods 5: 50-64. DOI: 10.3390/foods5030050.

Hu H, Liu W, Shi J, Huang Z, Zhang Y, Huang A, Yang M, Qin X, Shen F. 2016. Structure and functional properties of octenyl succinic anhydride modified starch prepared by a non-conventional technology. Starch 68: 151-159. DOI: 10.1002/star.201500195.

Kumoro AC, Amalia R, Retnowati DS, Budiyati CS, Ratnawati. 2014. Preparation and physicochemical characterization of modified (Acetylated) Gadung (Dioscorea hispida Dennst) flours. St Cerc St CICBIA 15: 135-148. DOI: 10.1016/j. jfoodeng.2011.08.006.

Mbougueng PD, Tenin D, Scher J, Tchiégang C. 2012. Influence of acetylation on physicochemical, functional and thermal properties of potato and cassava starches. J Food Eng 108: 320326. DOI: 10.1016/j.jfoodeng.2011.08.006.

Picauly P, Damamain E, Polnaya FJ. 2017. Karakteristik fisiko-kimia dan fungsional pati sagu ihur termodifikasi dengan heat moisture treatment. J Teknol Industri Pangan 28: 70-77. DOI: 10.6066/ jtip.2017.28.1.70.

Polnaya FJ, Haryadi, Marseno DW. 2008. Characteristics of hydroxypropylated and acetylated sago starches. Sago Palm 16: 85-94.

Polnaya FJ, Huwae AA, Tetelepta G. 2018. Karakteristik sifat fisiko-kimia dan fungsional pati sagu ihur (Metroxylon sylvestre) dimodifikasi dengan hidrolisis asam. Agritech 38: 7-15. DOI: DOI: 10.22146/agritech.16611.

Polnaya FJ, Talahatu J, Haryadi, Marseno DW. 2009. Karakterisasi tiga jenis pati sagu (Metroxylon sp). Hidroksipropil. Agritech 29: 8795.

Polnaya FJ, Puturuhu BRI. 2010. Preparasi dan karakterisasi pati sagu asetil. Buletin Penelitian BIAM 6: 10-13.

Sánchez-Rivera MM, Almanza-Benitez S, Bello-Perez LA, Mendez-Montealvo G, Núnez-Santiago MC, Rodriguez-Ambriz SL, Gutierrez-Meráz F. 2013. Acetylation of banana (Musa paradisiaca L.) and corn (Zea mays L.) starches using a microwave heating procedure and iodine as 
catalyst: II. Rheological and structural studies. Carbohyd Polym 92: 1256-1261. DOI: 10.1016/j. carbpol.2012.10.040.

Saputro MA, Kurniawan A, Retnowati DS. 2012. Modifikasi pati talas dengan asetilasi menggunakan asam asetat. J Teknol Kimia Industri 1: 258263.

Shah A, Masoodi FA, Gani A, Ashwar BA. 2017. Physicochemical, rheological and structural characterization of acetylated oat starches. LWTFood Sci Tech 80: 19-26. DOI: 10.1016/j.Iwt. 2017.01.072.

Simsek S, Ovando-Martínez M, Whitney K, BelloPérez LA. 2012. Effect of acetylation, oxidation and annealing on physicochemical properties of bean starch. Food Chem 134: 1796-1803. DOI: 10.1016/j.foodchem.2012.03.078.

Singh H, Sodhi NS, Singh N. 2012. Structure and functional properties of acetylated sorghum starch. Int J Food Prop 15: 312-325. DOI: 10.10 80/10942912.2010.483633

Singh N, Chawla D, Singh J. 2004. Influence of acetic anhydride on physicochemical, morpholo- gical and thermal properties of corn and potato starch. Food Chem 86: 601-608. DOI: 10.1016/j. foodchem.2003.10.008.

Teja AW, Sindi IP, Ayucitra A, Setiawan LEK. 2008. Karakteristik pati sagu dengan metode asetilasi dan cross-linking. J. Teknik Kimia Indonesia 7: 836-843. DOI: 10.5614/jtki.2008.7.3.4.

Wani IA, Sogi DS, Gill BS. 2012. Physicochemical properties of acetylated starches from some Indian kidney bean (Phaseolus vulgaris L.) cultivars. Int J Food Sci Technol 47: 1993-1999. DOI: 10.1111/j.1365-2621.2012.03062.x.

Wulandari E, Sukarminah E, Mardawati E, Furi HL. 2019. Profil gelatinisasi tepung sorgum putih termodifikasi $\alpha$-amilase. J Teknol Industri $\mathrm{Pa}$ ngan 30: 173-179. DOI: 10.6066/jtip.2019.30.2. 173.

Zięba T, Kapelko M, Szumny A. 2013. Effect of preparation method on the properties of potato starch acetates with an equal degree of substitution. Carbohyd Polym 94: 193-198. DOI: 10.101 6/j.carbpol.2013.01.002. 